\title{
Catabolism of Gentisic Acid by Two Strains of Bacillus stearothermophilus
}

\author{
By J. S. CLARK AND J. A. BUSWELL \\ Department of Biology, Paisley College of Technology, Paisley, \\ Renfrewshire PA1 2BE, Scotland
}

(Received 17 November 1978)

\section{INTRODUCTION}

Certain members of the genus Bacillus catabolize p-hydroxybenzoate to gentisic acid (2,5-dihydroxybenzoic acid) followed by oxidative ring-cleavage to yield maleylpyruvate. The ring-cleavage is catalysed by gentisate 1,2-dioxygenase which, together with enzymes catalysing the further dissimilation of maleylpyruvate, is induced in these bacteria by growth with $p$-hydroxybenzoate or benzoate (Buswell \& Clark, 1976; Crawford, 1976). Some species of the genus Pseudomonas degrade maleylpyruvate by a reduced glutathione (GSH)dependent cis, trans isomerization reaction to fumarylpyruvate which. in turn, is hydrolysed to fumaric and pyruvic acids (pathway B, Fig. 1; Lack, 1959, 1961; Tanaka et al., 1957; Hareland et al., 1975). Other species of Pseudomonas hydrolyse maleylpyruvate directly to maleate and pyruvate, without prior cis, trans isomerization, using a GSH-independent maleylpyruvate hydrolase (pathway A, Fig. 1; Hopper et al., 1968, 1971). In one species, Pseudomonas 2,5X, both GSH-independent and GSH-dependent enzymes are reported to exist (Crawford \& Frick, 1977).

In the gentisate-degrading bacilli so far described, catabolism of maleylpyruvate is not stimulated by GSH (Crawford, 1975, 1976); in some cases, maleate was identified as the end-product, thus providing direct evidence that maleylpyruvate can be hydrolysed by a GSH-independent maleylpyruvate hydrolase. These observations have been confirmed using $N$-ethylmaleimide (NEM) which inhibits the GSH-dependent cis, trans isomerization of maleylpyruvate to fumarylpyruvate but not the GSH-independent maleylpyruvate hydrolase (Crawford \& Frick, 1977). Buswell \& Clark (1976) also reported that GSH did not stimulate maleylpyruvate conversion by extracts of a facultative thermophilic Bacillus, implying that direct hydrolysis to pyruvic and maleic acids occurred, although maleate was not identified as a reaction product. The results of further examination of gentisate degradation in this and in a second strain of Bacillus stearothermophilus are now described. These results show that in one strain cis, trans isomerization of maleylpyruvate to fumarylpyruvate is catalysed by a NEM-sensitive enzyme, but in the other, gentisate is converted to fumarate and pyruvate in a GSH-independent reaction (pathway C, Fig. 1).

\section{METHODS}

The isolation and cultivation of one organism used in this study, a facultative thermophilic Bacillus species, was described previously (Buswell \& Clark, 1976). This bacterium has been tentatively identified as an atypical strain of Bacillus stearothermophilus, strain PM41. Bacillus stearothermophilus strain C1 was isolated from soil by elective culture with $p$-hydroxybenzoate at $55^{\circ} \mathrm{C}$ and cultured under the same conditions as PM41. Cell extracts were prepared and clarified as described previously (Buswell \& Clark, 1976).

Maleylpyruvate was prepared using a partially purified extract of PM41 cells grown with $p$-hydroxybenzoate. Crude extract was brought to $70 \%$ saturation with $\left(\mathrm{NH}_{4}\right)_{2} \mathrm{SO}_{4}$ solution, $\mathrm{pH} 7 \cdot 6$. Precipitated protein was collected by centrifugation, redissolved in $0.1 \mathrm{M}$-Tris/ $\mathrm{HCl}$ buffer, $\mathrm{pH} 7 \cdot 6$, and applied to a Sephadex G-150 column $(2.5 \times 90 \mathrm{~cm})$. The column was eluted with similar buffer and $5 \mathrm{ml}$ fractions were collected. Fractions 

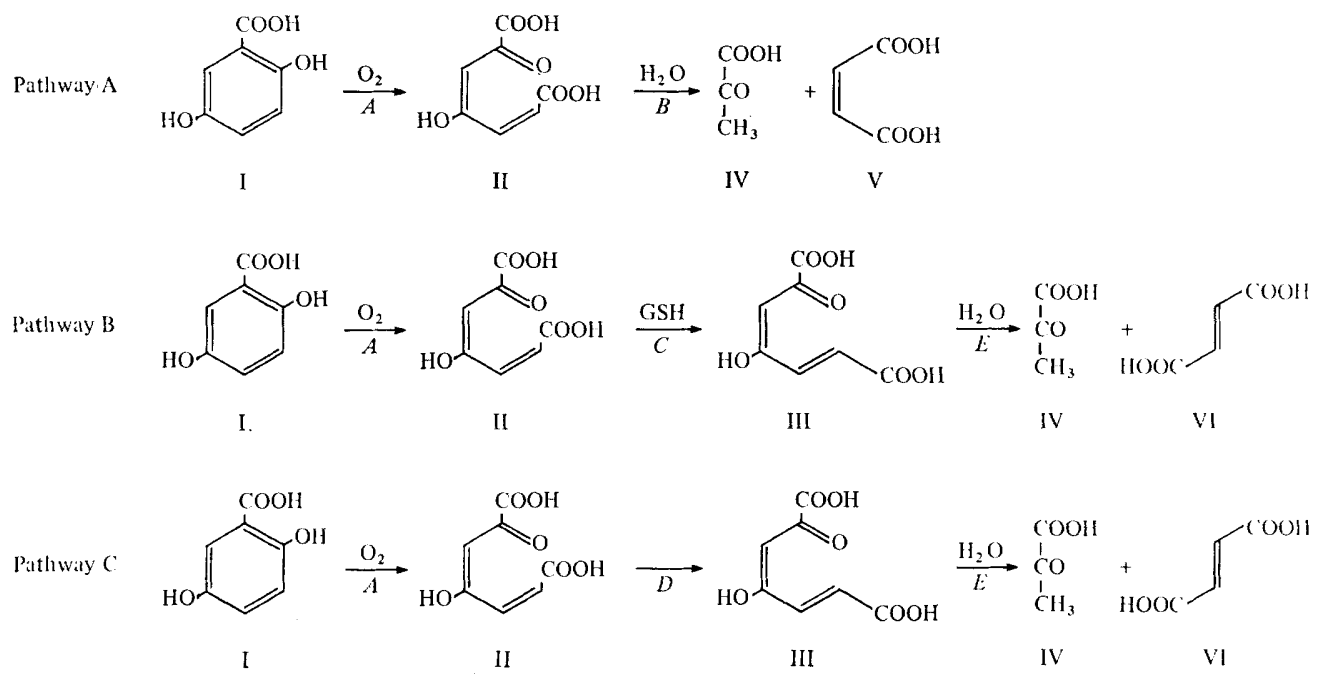

Fig. 1. Catabolism of gentisate by Bacillus spp.: pathway A, Bacillus spp. (Crawford, 1975, 1976); pathway B, B. stearothermophilus C1; pathway C, B. stearothermophilus PM41.

Compounds: I, gentisate; II, maleylpyruvate; III, fumarylpyruvate; IV, pyruvate; V, maleate; VI, fumarate.

Enzymes: $A$, gentisate 1,2-dioxygenase; $B$, maleylpyruvate hydrolase; $C$, GSH-dependent maleylpyruvate isomerase (NEM-sensitive); $D$, GSH-independent maleylpyruvate isomerase; $E$, fumarylpyruvate hydrolase.

38 to 65 , containing gentisate 1,2-dioxygenase but no maleylpyruvate-metabolizing enzyme activity, were pooled and brought to $70 \%$ saturation with $\left(\mathrm{NH}_{4}\right)_{2} \mathrm{SO}_{4}$. The precipitate was collected by centrifugation and redissolved in $0 \cdot 1 \mathrm{M}-\mathrm{KH}_{2} \mathrm{PO}_{4} / \mathrm{KOH}$ buffer, $\mathrm{pH} 7 \cdot 6$. Maleylpyruvate was prepared by incubating purified extract (approx. $10 \mathrm{mg}$ protein), $150 \mu \mathrm{mol}$ ferrous ammonium sulphate and $300 \mu \mathrm{mol}$ gentisate (adjusted to $\mathrm{pH} 7.0$ ) in $12 \mathrm{ml}$ of $0.1 \mathrm{M}-\mathrm{KH}_{2} \mathrm{PO}_{4} / \mathrm{KOH}$ buffer, $\mathrm{pH} \mathrm{7.6}$, at $30^{\circ} \mathrm{C}$ for $1.75 \mathrm{~h}$ in an orbital incubator shaker set at 80 rev. $\mathrm{min}^{-1}$. After this period the solution was diluted with an equal volume of water and the $\mathrm{pH}$ was adjusted to $7 \cdot 2$. Absolute ethanol $\left(5 \mathrm{vol}\right.$.) at $-18^{\circ} \mathrm{C}$ was added, the precipitated protein was removed by centrifugation, and the product was extracted by the procedure described by Lack (1961). Fumarylpyruvate was prepared by the procedure of Lack (1959).

Gentisate 1,2-dioxygenase [EC 1.13.11.4; gentisate: oxygen 1,2-oxidoreductase (decyclizing)] was assayed by measuring the rate of oxygen consumption at $50{ }^{\circ} \mathrm{C}$ with a Clark oxygen electrode. Assay mixtures

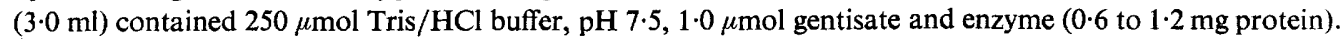
Enzymic conversion of maleylpyruvate was determined at $28{ }^{\circ} \mathrm{C}$ from the rate of decrease in absorbance at $330 \mathrm{~nm}$. Assay mixtures $(3.0 \mathrm{ml})$ contained $250 \mu \mathrm{mol}$ Tris $/ \mathrm{HCl}$ buffer, $\mathrm{pH} 7.5$, enzyme $(0.2$ to $0.5 \mathrm{mg}$ protein) and, to initiate the reaction, $100 \mathrm{nmol}$ maleylpyruvate (estimated by assuming that $\epsilon=13000$ at $330 \mathrm{~nm}$ ). Fumarylpyruvate hydrolase activity was measured at $28^{\circ} \mathrm{C}$ from the rate of decrease in absorbance at $340 \mathrm{~nm}$ resulting from hydrolysis of fumarylpyruvate to fumaric and pyruvic acids (Lack, 1959). Assay

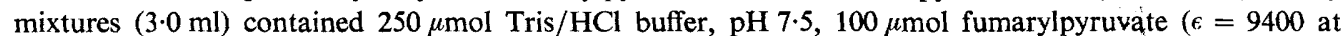
$340 \mathrm{~nm}$; Tanaka et al., 1957) and enzyme (40 to $95 \mu \mathrm{g}$ protein). Fumarate hydratase (EC 4.2.1.2; L-malate hydro-lyase) and maleate isomerase (EC 5.2.1.1; maleate cis-trans-isomerase) activities were assayed essentially as described by Scher \& Jakoby (1969). Freshly prepared extracts were used at all times. Assays were performed at 28 and $50^{\circ} \mathrm{C}$, the same patterns of activity and inhibition being observed at both temperatures. Dicarboxylic acids were identified as their dimethyl esters by gas-liquid chromatography (g.l.c.). Mass spectroscopy was performed on a VG model $16 \mathrm{~F}$ linked to a VG 2020 data system. Protein was measured by the method of Lowry et al. (1951).

\section{RESULTS AND DISCUSSION}

The metabolism of benzoate and $p$-hydroxybenzoate was examined in 19 strains of thermophilic bacilli isolated from different sources. When bacteria were grown on either of these compounds, extracts of all isolates contained gentisate 1,2-dioxygenase activity. Strains $\mathrm{Cl}$ 
Table 1. Effect of $N$-ethylmaleimide $(N E M)$ on conversion of maleylpyruvate by extracts of $B$. stearothermophilus strains PM41 and $\mathrm{Cl}$

\begin{abstract}
Conversion of maleylpyruvate was assayed as described in Methods. Where indicated, $1.0 \mathrm{mM}-\mathrm{NEM}$ was added to the reaction mixture 2 min before addition of substrate. When no NEM was added, the reaction was initiated 2 min after addition of extract to the reaction mixture. Specific activities are expressed as $\mathrm{nmol} \mathrm{min}^{-1}(\mathrm{mg} \text { protein })^{-1}$.
\end{abstract}

\begin{tabular}{|c|c|c|c|c|}
\hline \multirow[b]{2}{*}{ Strain } & \multirow[b]{2}{*}{ Growth substrate } & \multicolumn{2}{|c|}{ Specific activity } & \multirow{2}{*}{$\begin{array}{c}\text { Activity } \\
\text { remaining } \\
(\%)\end{array}$} \\
\hline & & $\begin{array}{l}\text { Without } \\
\text { NEM }\end{array}$ & $\begin{array}{l}\text { With } \\
\text { NEM }\end{array}$ & \\
\hline $\begin{array}{l}\text { PM41 } \\
\text { PM41 }\end{array}$ & $\begin{array}{l}\text { Benzoate } \\
p \text {-Hydroxybenzoate }\end{array}$ & $\begin{array}{l}56 \cdot 8 \\
592\end{array}$ & $\begin{array}{l}55 \cdot 8 \\
592\end{array}$ & $\begin{array}{r}98 \\
100\end{array}$ \\
\hline $\begin{array}{l}\mathrm{C} 1 \\
\mathrm{C} 1\end{array}$ & $\begin{array}{l}\text { Benzoate } \\
p \text {-Hydroxybenzoate }\end{array}$ & $\begin{array}{l}242 \\
252\end{array}$ & $\begin{array}{l}13 \cdot 3 * \\
15 \cdot 0^{*}\end{array}$ & $\begin{array}{l}5 \cdot 5 \\
6 \cdot 0\end{array}$ \\
\hline
\end{tabular}

* Non-linear rate: specific activity calculated on the basis of maleylpyruvate conversion during the first $3 \mathrm{~min}$.

and PM41, tentatively identified as strains of Bacillus stearothermophilus (Gordon et al., 1973), were selected for further study.

Extracts of $B$. stearothermophilus $\mathrm{Cl}$ grown with benzoate or $p$-hydroxybenzoate oxidized gentisate but not catechol or protocatechuate. Direct evidence that gentisate is an intermediate in $p$-hydroxybenzoate catabolism by this bacterium was obtained using $2,2^{\prime}$ bipyridyl to inhibit the ring-cleavage enzyme (Hopper \& Chapman, 1971; Buswell \& Clark, 1976). The product which accumulated from $p$-hydroxybenzoate was identified as gentisate by thin-layer chromatography and mass spectrometry. The activities of gentisate 1,2dioxygenase [8.7 and $1.4 \mu \mathrm{l}$ oxygen consumed $\mathrm{min}^{-1}$ (mg protein) ${ }^{-1}$ after growth with benzoate or $p$-hydroxybenzoate, respectively] were increased 30 -fold and 5 -fold compared with the activity in extracts of non-induced bacteria grown with fumarate. This is in contrast to induction patterns previously reported for strain PM41 in which much higher activities of the ring-fission enzyme were induced by $p$-hydroxybenzoate (Buswell \& Clark, 1976).

When GSH $(0.3 \mu \mathrm{mol})$ was included in reaction mixtures, the rate of maleylpyruvate dissimilation by crude extracts of $\mathrm{C} 1$ grown with benzoate increased by 10 to $15 \%$. Short periods of dialysis did not enhance the GSH-dependence of this enzyme. However, the rate of maleylpyruvate conversion by unsupplemented extracts was inhibited approximately $95 \%$ by $1 \mathrm{~mm}$-NEM (Table 1$)$. Excess GSH $(0.3 \mu \mathrm{mol})$ restored only about $10 \%$ of the original activity. Fumarate was identified by g.l.c. as a reaction product. Fumarylpyruvate hydrolase was active in extracts of bacteria grown with benzoate or $p$-hydroxybenzoate [specific activities were 0.51 and $0.52 \mu \mathrm{mol} \mathrm{min}^{-1}(\mathrm{mg} \text { protein })^{-1}$, respectively] but fumarate hydratase and maleate isomerase were not detected. Although a non-specific inhibition of maleylpyruvate metabolism by NEM cannot be excluded, these results strongly indicate that strain $\mathrm{Cl}$ catalyses a GSH-dependent cis, trans isomerization of a type not previously reported in members of this genus.

NEM (1 mM) did not inhibit maleylpyruvate catabolism by extracts of strain PM41 (Table 1). This is consistent with an earlier report that the rate of maleylpyruvate conversion was not enhanced by GSH (Buswell \& Clark, 1976). Although these results suggested that maleylpyruvate was hydrolysed directly to pyruvate and maleate (pathway A, Fig. 1), fumaric acid has now been identified as a reaction product. Therefore, in strain PM41, maleylpyruvate is isomerized to fumarylpyruvate by a GSH-independent enzyme. Cell extracts did not contain maleate isomerase.

Hagedorn et al. (1977) demonstrated a transient accumulation of fumarylpyruvate by extracts of Bacillus megaterium which had been grown with benzoate or $m$-hydroxybenzoate and they too suggested that a GSH-independent cis, trans isomerization had occurred. No 
fumarylpyruvate accumulated during maleylpyruvate metabolism by strain PM41, but this was probably because it was degraded as rapidly as it was formed; the specific activities of fumarylpyruvate hydrolase were 0.074 and $0.72 \mu \mathrm{mol} \mathrm{min}^{-1}(\mathrm{mg} \text { protein) })^{-1}$ after growth with benzoate or $p$-hydroxybenzoate, respectively. Attempts to separate maleylpyruvate isomerase from fumarylpyruvate hydrolase have so far been unsuccessful because these enzymes are unstable during purification.

Maleylpyruvate isomerase activity in crude extracts of strains PM41 and $\mathrm{Cl}$ was proportional to protein concentration $(0.1$ to $0.9 \mathrm{mg})$ and no substrate inhibition was evident (see Lack, 1961). However, the isomerase of both organisms is unstable and the normal linear rate of activity observed spectrophotometrically progressively decreased during the assay, a response seen within hours of extract preparation in the case of strain $\mathrm{Cl}$. Extracts prepared in buffer containing $10 \mathrm{~mm}$-dithiothreitol did not exhibit this loss of activity even after several weeks at $-20^{\circ} \mathrm{C}$. Similarly, when assays were initiated with substrate, prior dilution of non-stabilized extracts in the reaction cuvette greatly reduced the extent of the linear rate compared with that observed when the reaction was initiated by addition of extract. Products of isomerase and hydrolase activities were not inhibitory and the reasons for this response are under investigation. Fumarylpyruvate hydrolase activity in extracts of strains $\mathrm{Cl}$ and PM41 was not significantly affected by NEM (1 mM) and was stable for at least a month at $-20^{\circ} \mathrm{C}$.

The reactions by which benzoate and $p$-hydroxybenzoate are converted to gentisate remain obscure because, as Crawford (1976) has reported for Bacillus laterosporus, cell-free extracts are not active towards the growth substrates. Two possible alternatives for $p$ hydroxybenzoate degradation - dehydroxylation to benzoate followed by hydroxylation at C-2 and C-5 of the ring, or hydroxylation at C-1 with concomitant migration of the carboxyl group to an ortho position - have been documented (Crawford, 1976). Extracts of strains $\mathrm{Cl}$ and PM41 grown with benzoate or $p$-hydroxybenzoate contain high activities of an inducible NADH (or NADPH)-dependent $m$-hydroxybenzoate-6-hydroxylase activity. The possible role of $m$-hydroxybenzoate as an intermediate in the degradation pathways is the subject of further study.

We thank Dr G. R. Jamieson and Elizabeth Reid of the Chemistry Department, Paisley College, for the g.l.c. analyses, and Dr D. B. Harper, Queens University, Belfast, for mass spectra. A grant-in-aid for equipment from the Royal Society to J.A.B. is gratefully acknowledged.

\section{REFERENCES}

Buswell, J. A. \& Clark, J. S. (1976). Oxidation of aromatic acids by a facultative thermophilic Bacillus sp. Journal of General Microbiology 96, 209-213.

CRAWFord, R. L. (1975). Degradation of 3-hydroxybenzoate by bacteria of the genus Bacillus. Applied Microbiology 30, 439-444.

Crawford, R. L. (1976). Pathways of 4-hydroxybenzoate degradation among species of Bacillus. Journal of Bacteriology 127, 204-210.

Crawford, R. L. \& Frick, T. D. (1977). Rapid spectrophotometric differentiation between glutathione-dependent and glutathione-independent gentisic and homogentisic pathways. Applied and Environmental Microbiology 34, 170-174.

Gordon, R. E., Haynes, W. C. \& Pang, C.-H. N. (1973). Agriculture Handbook No. 427. U.S. Government Printing Office.

Hagedorn, S. R., Keenan, S. L. \& Chapman, P. J. (1977). Benzoate metabolism by Bacillus mega- terium. Abstracts of the Annual Meeting of the American Society for Microbiology, Q86, p. 275.

Hareland, W. A., Crawford, R. L., Chapman, P. J. \& Dagley, S. (1975). Metabolic function and properties of 4-hydroxyphenylacetic acid 1-hydroxylase from Pseudomonas acidovorans. Journal of Bacteriology 121, 272-285.

Hopper, D. J. \& Chapman, P. J. (1971). Gentisic acid and its 3. and 4-methyl-substituted homologues as intermediates in the bacterial degradation of $m$-cresol, 3,5-xylenol and 2,5-xylenol. Biochemical Journal 122, 29-40.

Hopper, D. J., Chapman, P. J. \& DaGley, S. (1968). Enzymic formation of D-malate. Biochemical Journal 110, 798-800.

Hopper, D. J., Chapman, P. J. \& Dagley, S. (1971). The enzymic degradation of alkylsubstituted gentisates, maleates and malates. Biochemical Journal 122, 29-40. 
LACK, L. (1959). The enzymic oxidation of gentisic Scher, W. \& JAKoby, W. B. (1969). Maleate isoacid. Biochimica et biophysica acta 34, 117-123.

LACK, L. (1961). Enzymic cis, trans isomerisation of maleylpyruvic acid. Journal of Biological Chemistry 236, 2835-2840.

Lowry, O. H., Rosebrough, N. J., Farr, A. L. \& RANDALL, R. J. (1951). Protein measurement with the Folin phenol reagent. Journal of Biological Chemistry 193, 265-275. merase. Journal of Biological Chemistry 244, 1878-1882.

Tanaka, H. S., Sugiyama, S., Yano, K. \& Arima, K. (1957). Isolation of fumarylpyruvic acid as an intermediate of gentisic acid oxidation by Pseudomonas ovalis var. S-5. Bulletin of the Agricultural Chemical Society of Japan 21, 67-68. 